\title{
Nisin Activity Against Contaminant Bacteria Isolated From Bioethanol Fermentation Tanks
}

Natalia Maia (I), Rachel Rigotti (I), Renata Silva (I), Bruna Lange (I), Giuseppe Meca (II), Renata Macedo (I), Fernando Luciano (I)

(I) PUC - PR - Pontifícia Universidade Católica do Paraná (BR 376 Km 14, São José dos Pinhais, PR, Brazil 83010-500), (II) UV - ES - University of Valencia (Av. Vicent Andrés Estellés s/n, 46100 Burjassot, Spain)

\section{Resumo}

Nisin is a bacteriocin (lantibiotic) produced by Lactococcus lactis, which is widely used in the food industry as a natural antimicrobial to avoid the growth of pathogenic and spoilage bacteria.The objective of the present work was to evaluate the antimicrobial activity of nisin to wards Leuconostoc mesenteroides and Lactobacillus fermentum, which are common contaminants in Brazilian bioethanol production plants. These bacteria are normally present in the wort and significantly reduce the sugarto-ethanol conversion capacity of Saccharomyces cerevisiae. Firstly, the Minimum Inhibitory Concentration (MIC) of nisin was determined for each one of the bacteria in tubes containing CSN broth (supplemented sugarcane broth). Then, a wide range of nisin doses was tested $(0.125-7,500 \mathrm{ppm})$ during CSN (10 oBRIX and $\mathrm{pH} 5,0)$ fermentation. The broth was coinoculated with Saccharomyces cerevisiae, Lactobacillus fermentum and Leuconostoc mesenteroides and incubated for $24 \mathrm{~h}$ at $30 \mathrm{oC}$. Then, samples from each batch were submitted to microbial count, oBRIX analysis, yeast viability and determination of ethanol content. All tests were performed 3 times in duplicate $(\mathrm{n}=6)$. The MIC for both bacteria was $0.75 \mathrm{ppm}$. The average bacterial population in the control group (non-treated samples) was $10.4 \log \mathrm{UFC} / \mathrm{mL}$ after the fermentation period. The lowest dose used, $0.125 \mathrm{ppm}$, did not present significant reduction of the bacterial contamination. However, all other doses presented a drastic of the bacterial population: $4.3 \log \mathrm{UFC} / \mathrm{mL}$ with $0.375 \mathrm{ppm} ; 5.8 \log \mathrm{UFC} / \mathrm{mL}$ with 0.75

\footnotetext{
Referência:

Natalia Maia, Rachel Rigotti, Renata Silva, Bruna Lange, Giuseppe Meca (II), Renata Macedo, Fernando Luciano. Nisin Activity Against Contaminant Bacteria Isolated From Bioethanol Fermentation Tanks. In: Anais do 12을 Congresso Latinoamericano de Microbiologia e Higiene de Alimentos - MICROAL 2014 [= Blucher Food Science Proceedings, num.1, vol.1]. São Paulo: Editora Blucher, 2014. DOI 10.5151/foodsci-microal-339
} 
ppm (=CIM), $5.7 \log \mathrm{UFC} / \mathrm{mL}$ with $7.5 \mathrm{ppm}, 7.5 \log \mathrm{UFC} / \mathrm{mL}$ with 750 ppm; and > $9.4 \log \mathrm{CFU} / \mathrm{mL}$ with 7,500 ppm. None of the doses tested presented a significant reduction of Saccharomyces cerevisiae population, and the yeast viability was always $>95 \%$. Groups treated with $\geq 0,75 \mathrm{ppm}$ presented lower o BRIX values and higher ethanol concentration than the control group. These results show that nisin may be used as a natural antibacterial agent during the production of bioethanol in order to reduce the population of Lactobacillus fermentum and Leuconostoc mesenteroides, and, consequently, increase the sugar-to-ethanol conversion rate by Saccharomyces cerevisiae.

Palavras-Chave: Bioethanol, Natural Antimicrobial, Bacterial Contamination, Bacteriocins

Agência de Fomento: 